\title{
Checking Adulteration of Aromatic, Amylose Content and Glutinous in Rice by Using Molecular Marker
}

\author{
Atirada Boondech ${ }^{1, a^{*}}$, Sunisa Sajaw ${ }^{1, b}$ \\ ${ }^{1}$ Biology program, faculty of Science and Technology Kamphaeng Phet Rajabhat University \\ 69 Nakorn Chum, Muang Kamphaeng Phet Province 62000, Thailand \\ a atirada@hotmail.com, ${ }^{b}$ aomjaw.sunisa@gmail.com
}

Keywords: adulteration, aromatic, amylose content and glutinous

\begin{abstract}
The purification of rice varieties were tested by using molecular markers. DNA fingerprint is the most accurate method. This research was extracted single milled rice seed varieties, which includes Proteinase $\mathrm{K}$ in SDS extraction buffer and $2 \mathrm{x}$ CTAB. Three simple sequence repeats (SSRs) markers for varietal purity test are 1) BO3, which completely co-segregate with the rice grain aroma. This primer pair amplifying a $140 \mathrm{bp}$ fragment for an aromatic variety, KDML105 and a 130 bp fragment for a non-aromatic variety, RD29, 41, 49 and rice berry, respectively. 2) RM190, which is closely linked to waxy gene. This primer pair amplifying a 125 bp fragment for low amylose content, Sao-hai, RD 29, RD 41, RD 49 rice varieties and a $110 \mathrm{bp}$ fragments for high amylose varieties, rice berry, KDML 105 and 3) Glu23, which is glutinous marker. This primer pair amplifying a 196 bp fragment for a non-glutinous variety, RD 29, RD 41, $\mathrm{RD} 49$, rice berry and a $225 \mathrm{bp}$ fragments for glutinous varieties, Keaw-Ngoo sticky rice. All markers can be checking adulteration of aromatic, amylose content and glutinous in rice by using molecular Marker.
\end{abstract}

\section{Introduction}

Rice (Oryza sativa L.) is one of the world's most important crops and a primary food for more than a third of the world's population. In Thailand, rice is not only importance as a staple food but also as an economic crop. One of export problem is contaminated non-aroma, amylose content and glutinous in rice. DNA fingerprinting is the most accurate method by using SSRs markers. Also, the availability of many SSR markers in rice helps the breeders for crop improvement through molecular marker assisted breeding [1]. BO3 DNA marker located at region of the chromosome 8 [2]. RM190-6 DNA marker was closely-linked to a waxy gene on chromosome 6 [3]. Glu23-6F /R was glutinous marker on chromosome 6 [3]. The objective of this study was to use gene marker of aromatic, low amylose content, glutinous genes.

\section{Method of Experiment}

Rice material. Rice seeds of RD 29, RD 41, RD 49 rice varieties were obtained from Kamphaeng Phet rice seed center, Thailand. Thai jasmine rice or Kow Dok Mali 105 (KDML 105), Bua Chompoo rice brand, Sao-hai, rice berry and Keaw-Ngoo sticky rice brand and random sampling were used to comparative in this experiment.

\section{Oligonucleotides.}

Table 1 List of oligonucleotide and sequence

\begin{tabular}{llll}
\hline Marker designation & Primer sequence 5'-3' & Fragment size (bps) & Linked gene \\
\hline BO3-8F & CGT GGC TCG ACC TTT TTA AT & 140 (aromatic) & Grain aroma \\
BO3-8R & TCA AAC CCT GGT TAC AGC AA & 130 (non-aromatic) & \\
\hline RM190-6F & CTT TGT CTA TCT CAA GAC AC & 125 (low amylose content) & Waxy gene \\
RM190-6R & TTG CAG ATG TTC TTC CTG ATG & 110 (high amylase content) & \\
\hline Glu-23-6F & TGC AGA GAT CTT CCA CAG CA & 225 (glutinous) & Waxy gene \\
Glu-23-6R & GCT GGT CGT CAC GCT GAG & 196 (non-glutinous) & \\
\hline
\end{tabular}


DNA extraction and DNA amplification. Each rice variety was sampling for DNA isolation. Rice seed was incubated in extraction buffer for 3 and 12 hour at $37^{\circ} \mathrm{C}$. Rice was homogenized by grinding with pestle in sterile microcentrifuge tube containing DNA of rice sample DNA of rice sample was extracted following the CTAB solution that containing $0.008 \mathrm{ug} / \mathrm{ul}$ of proteinase $\mathrm{K} 400$ ul [4]. The reaction were mixed and incubated for 30 minus- 3 hour at $65{ }^{\circ} \mathrm{C}$. The solution was incubated f 5 minus at $-20^{\circ} \mathrm{C}$. Phenol, Chloroform, Isoamyl alcohol in ratio 25:24:1 were added with 400 microliters. The reaction was centifugated in $12,000 \mathrm{rpm}$ at 10 minus. DNA were collected with cool absolute ethyl alcohols.

DNA reaction was a template with the same component but difference primers (Table 1). The actin rice was used as housekeeping gene control. The polymerase chain reaction (PCR) mixture $(10 \mu \mathrm{l})$ contained $5 \mu \mathrm{l} 2 \mathrm{X}$ PCR Master (Mix Fermentas, USA) containing 0.05 units $/ \mu 1$ Taq DNA Polymerase in reaction buffer, $4 \mathrm{mM} \mathrm{MgCl} 2,0.4 \mathrm{mM}$ dATP, $0.4 \mathrm{mM} \mathrm{dCTP}, 0.4 \mathrm{mM}$ dGTP and $0.4 \mathrm{mM}$ dTTP $1 \mu \mathrm{l}$ of $10 \mu$ mole forward primer, $1 \mu \mathrm{l}$ of $10 \mu$ mole reverse primer, $2 \mu \mathrm{l}$ of nuclease free water and $1 \mu \mathrm{L}$ DNA template. The PCR-amplification was performed with temperature program consisting of initial denature $\left(94{ }^{\circ} \mathrm{C}, 3 \mathrm{~min}\right)$ and 30 cycles of denature $\left(94{ }^{\circ} \mathrm{C}, 1 \mathrm{~min}\right)$, primer annealing temperature according to $\mathrm{Tm}$ of each gene $\left(55-61{ }^{\circ} \mathrm{C}\right)$ and primer extension $\left(72{ }^{\circ} \mathrm{C}, 1 \mathrm{~min}\right)$. For final extension, this was followed by incubation at $72{ }^{\circ} \mathrm{C}$ for $10 \mathrm{~min}$. A volume of $5 \mu \mathrm{l}$ of the PCR product was analyzed by electrophoresis in $1 \%$ agarose gel.

Gel electrophoresis. The amplified PCR products were analyzed by electrophoresis on $1 \%$ agarose gel. Agarose gel electrophoresis was performed. Agarose powder was dissolved in 0.5X TBE buffer (Tris $\mathrm{pH} 7.5$, Boric acid, EDTA $\mathrm{pH}$ 8.) to obtain $1 \%(\mathrm{w} / \mathrm{v})$ agarose gel. After boiling to ensure the homogeneity of the gel solution, the gel mixture was cooled down and poured into the mold to solidity at room temperature. Gel loading dye was mixed with DNA in a ratio of 1:5 (v/v) and then the mixture was loaded into a well of agarose gel submerged in TBE buffer. After electrophoresis setting constant voltage at 50 volts was completed, the gel was stained in $5 \mu \mathrm{g} / \mathrm{ml}$ ethidium bromide solution for $10 \mathrm{~min}$. and destained in water for $10 \mathrm{~min}$. The DNA bands were visualized under UV light by the Geldocs system (Syngene, U.K). The size of DNA was estimated by comparing the stained DNA band with standard DNA marker concentration under UV light.

\section{Results and Dicussion}

The ratio of $\mathrm{OD}_{260} / \mathrm{OD}_{280}$, the extracted total DNA was $1.9-2.1$. The amplification of the primer pair specific to actin was examined by PCR (Fig. 1). The expected amplification product of $400 \mathrm{bp}$ in size was obtained indicating the acceptable quality of DNA. Size of PCR product was determined by $1 \%$ agarose gel electrophoresis. The expected amplification product, $540 \mathrm{bp}$ in size of actin gene were obtained. The results showed the screening incubation time, 3 hour or overnight, with proteinase $\mathrm{K}^{+}$extraction buffer and SDS buffer. The maximal expression level was achieved after overnight incubation (Fig 1)

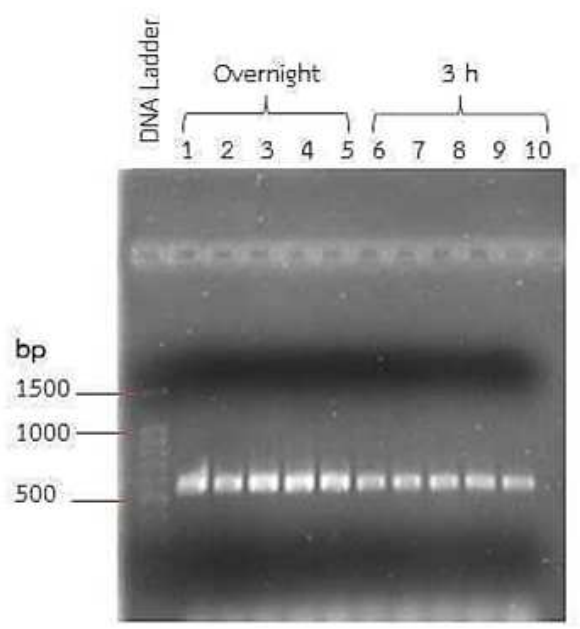

Fig 1. The ethidium bromide stained agarose gel showing the amplification results of actin gene, $540 \mathrm{bp}$ that were example of DNA extraction after overnight incubation. 
DNA fingerprint was screening aromatic and non-aromatic DNA fragment in rice chromosome 8 with $\mathrm{BO} 3-8 \mathrm{~F} / \mathrm{R}$ primers of the. This primer pair amplifying a $140 \mathrm{bp}$ fragment for an aromatic variety, KDML105 standard and sampling rice from no brand in general markets. The $130 \mathrm{bp}$ fragment for non-aromatic, RD29, 41, 49 and rice berry, were shown in fig 2.
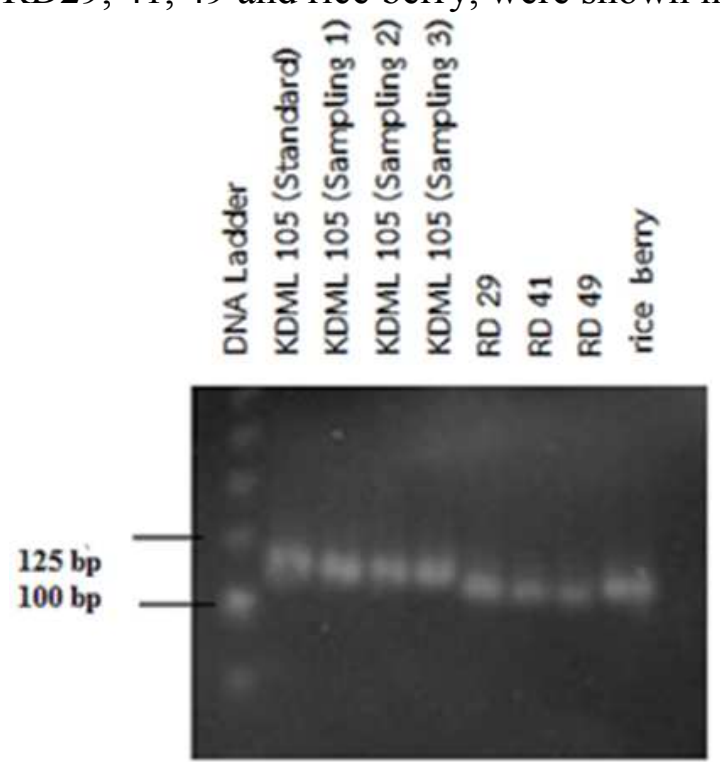

Fig 2. The ethidium bromide stained agarose gel showing the amplification results of aromtic (140 bp) or non-aromatic gene (130 bp) expected sized. A 25 bp DNA ladder (Bio rad) was used as a size standard.

DNA fingerprint was screening high and low-amylose content DNA fragment in rice chromosome 6 with RM190-6 F /R primers. This primer pair were amplified a 125 bp fragment for a low amylose, KDML105 standard and rice berry sampling. The $110 \mathrm{bp}$ fragment for glutinous, sampling of Sao-hai brand, RD29, RD 41, and RD 49 rice were shown in fig 3. The results showed the low and height -amylose content in rice markers.

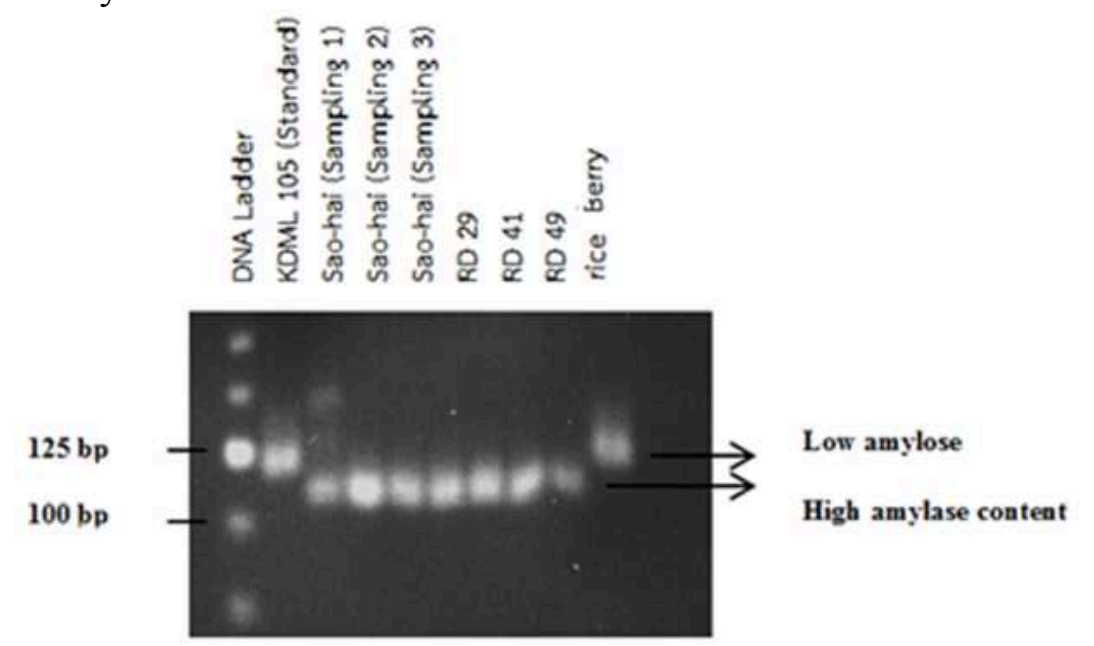

Fig 3. The ethidium bromide stained agarose gel showing the amplification results of low amylose content (125 bp) or high amylase content (110 bp) expected sized. A 25 bp DNA ladder (Bio rad) was used as a size standard.

DNA fingerprint was screening glutinous and non-glutinous content DNA fragment in rice chromosome 6 with Glu23-6F /R primers. This primer pair were amplified $196 \mathrm{bp}$ fragment for a non-glutinous, RD 29, 41, 49 and rice berry. The 225 bp of fragment for glutinous, Keaw-Ngoo sticky rice (standard) were shown in lane 2. In addition, all random of sampling form no brand of sticky rice that brought from general markets were shown $225 \mathrm{bp}$ fragment in fig 4. 


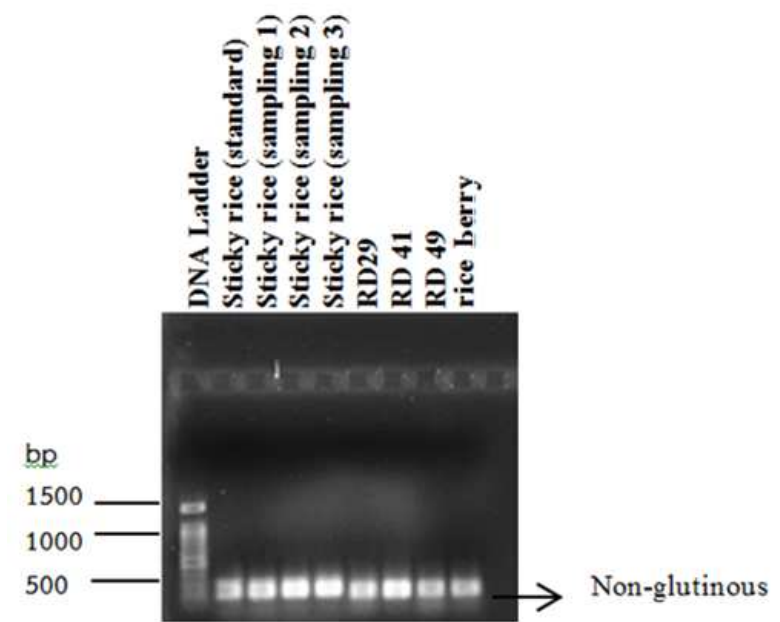

Fig 4. The ethidium bromide stained agarose gel showing the amplification results of glutinous, $225 \mathrm{bp}$, and non-glutinous, $196 \mathrm{bp}$, expected sized. A $100 \mathrm{bp}$ DNA ladder (Bio rad) was used as a size standard

Currently, several molecular marker techniques are available in serving various purposes in different crops. Finally, the use of unique primer sequence method will greatly enhance the ability to develop PCR-based markers and will improve the efficiency of aromatic, amylose content, and glutinous classification in rice grain. However, many SSR molecular markers have identified in rice which classified by using another cluster analysis.

\section{Summary}

In this study, BO3-8 primers were identified aromatic or non-aromatic rice. RD29, RD 41, RD 49 and rice berry were detected in non-aromatic rice group, $130 \mathrm{bp}$. KDML105 standard and sampling are aromatic rice, $140 \mathrm{bp}$. Amylose content in rice was identified with RM190-6 primers. KDML and berry rice are low amylose content rice that were amplified a $125 \mathrm{bp}$ fragment for a low amylose. Height amylose content are sampling of Sao-hai brand, RD29, RD 41, and RD 49. KeawNgoo sticky rice brand are glutinous, 225 bp, and non-glutinous, 196 bp, are RD29, RD 41, and RD 49.

\section{References}

[1] S. R. McCouch, L. Teytelman, Y. Xu, K. B. Lobos, K. Clare, M. Walton, B. Fu, R. Maghirang, Z. Li, Y. Xing, Q. Zhang, I. Kono, M. Yano, R. Fjellstrom, G. De Clerck, D. Schneider, S. Cartinhour, D. Ware, L. Stein, 2002. Development and mapping of 2240 new SSR markers for rice (Oryza sativa L.). DNA Res, pp.199-207.

[2] S. Wanchana, W. Kamolsukyunyoung, S. Ruengphayak, S. Tragoonrung, T. Toojinda and A. Vanavichit, 2005. A rapid construction of a physical contig across a $4.5 \mathrm{cM}$ region for rice grain aroma facilitates marker enrichment for positional Cloning. Sci. Asia 31 : pp. 299-306.

[3] S. Wanchana, T. Toojinda, S. Tragoonrung and A. Vanavichit, 2003. Duplicated coding sequence in the waxy allele of tropical glutinous rice (Oryza sativa L.) Plant Science. pp. 11931199.

[4] C. Payorm, C. Varapong, M. Poonsak, Thai Rice Research Journal, 2007. 